\title{
Influence of Acute High Glucose on Protein Abundance Changes in Murine Glomerular Mesangial Cells
}

\author{
Michelle T. Barati, ${ }^{1}$ James C. Gould, ${ }^{1,2}$ Sarah A. Salyer, ${ }^{1,3}$ Susan Isaacs, ${ }^{1}$ \\ Daniel W. Wilkey, ${ }^{1}$ and Michael L. Merchant ${ }^{1}$ \\ ${ }^{1}$ Kidney Disease Program, Department of Medicine, University of Louisville, Louisville, KY 40202, USA \\ ${ }^{2}$ Harvard Medical School, Boston, MA 02115, USA \\ ${ }^{3}$ Tuskegee University School of Veterinary Medicine, Tuskegee, AL 36088, USA
}

Correspondence should be addressed to Michael L. Merchant; mlmerc02@louisville.edu

Received 9 August 2015; Revised 22 November 2015; Accepted 30 November 2015

Academic Editor: Feng Zheng

Copyright (C) 2016 Michelle T. Barati et al. This is an open access article distributed under the Creative Commons Attribution License, which permits unrestricted use, distribution, and reproduction in any medium, provided the original work is properly cited.

The effects of acute exposure to high glucose levels as experienced by glomerular mesangial cells in postprandial conditions and states such as in prediabetes were investigated using proteomic methods. Two-dimensional gel electrophoresis and matrix assisted laser desorption ionization time of flight mass spectrometry methods were used to identify protein expression patterns in immortalized rat mesangial cells altered by $2 \mathrm{~h}$ high glucose (HG) growth conditions as compared to isoosmotic/normal glucose control $\left(\mathrm{NG}^{*}\right)$ conditions. Unique protein expression changes at $2 \mathrm{~h}$ HG treatment were measured for 51 protein spots. These proteins could be broadly grouped into two categories: (1) proteins involved in cell survival/cell signaling and (2) proteins involved in stress response. Immunoblot experiments for a protein belonging to both categories, prohibitin (PHB), supported a trend for increased total expression as well as significant increases in an acidic PHB isoform. Additional studies confirmed the regulation of proteasomal subunit alpha-type 2 and the endoplasmic reticulum chaperone and oxidoreductase PDI (protein disulfide isomerase), suggesting altered ER protein folding capacity and proteasomal function in response to acute HG. We conclude that short term high glucose induces subtle changes in protein abundances suggesting posttranslational modifications and regulation of pathways involved in proteostasis.

\section{Introduction}

Renal glomerular mesangial cells (GMCs) functions are altered in diabetic nephropathy by chronic exposure to high glucose (HG) or exposure to glycated albumin [1-4]. The early effects of hyperglycemia are thought to be dominated by hemodynamic factors including glomerular hyperfiltration and shear stress leading to damage by microalbuminuria or proteinuria [5-10]. The early histopathology of diabetic nephropathy is characterized by a thickening of the glomerular basement membrane (GBM) and an accumulation of extracellular matrix (ECM) in the glomerular mesangium. The damaging effects of chronic hyperglycemia on various kidney glomerular cell types such as mesangial cells, podocytes, and endothelial cells have been intensely studied.
The theories that have been addressed include increased substrate channeling into the polyol pathway and the hexosamine pathways and increased production of reactive oxygen species (ROS) and activation of protein kinase C (via advanced glycation end-products (AGE), diacylglycerols (DAG), and/or reactive oxygen species (ROS)) [11-13]. These advances in our understanding of the effects of chronic hyperglycemia on renal physiology have not been matched by understanding of the effects of acute $(2 \mathrm{~h})$ hyperglycemic conditions episodically experienced by cells like the GMC in states such as prediabetes. We hypothesize that understanding these acute changes induced by hyperglycemia might yield insight into the mechanisms through which chronic hyperglycemia disrupts mechanisms used to maintain normal glomerular function. 


\section{Material and Methods}

2.1. Cell Culture. The rat GMC line CRL-2573 (ATCC) maintained normal growth media (DMEM: $5 \mathrm{mM} \mathrm{D}$-glucose, $15 \% \mathrm{FBS}$ ) under $5 \% \mathrm{CO}_{2}$ at $37^{\circ} \mathrm{C}$. The cells (passages $10-15$ ) were plated in Corning T25 flasks and cultured until 70$80 \%$ confluence was reached. Normal media were removed from cells and replaced with DMEM supplemented with $0.5 \% \mathrm{FBS} / 5 \mathrm{mM} \mathrm{D}$-glucose. After $24 \mathrm{~h}$, media were removed and replaced with isoosmotic-normal glucose $\left(\mathrm{NG}^{*}\right)$ media (DMEM-5 mM D-glucose, $20 \mathrm{mM}$ mannitol, and 0.5\% FBS) or high glucose (HG) media (DMEM: $25 \mathrm{mM}$ D-glucose, $0 \mathrm{mM}$ mannitol, and $0.5 \% \mathrm{FBS}$ ), for $2 \mathrm{~h}$. For $2 \mathrm{DE}$ analysis, after $2 \mathrm{~h}$ treatment, the total protein was collected as previously described [14] using IPG rehydration buffer supplemented with protease inhibitors.

2.2. Cell Viability. Cell viability was determined after $2 \mathrm{~h} \mathrm{HG}$ and $\mathrm{NG}^{*}$ treatment using the MTT assay [15] as described by the manufacturer (Sigma, St. Louis, MO, USA).

2.3. Two-Dimensional Electrophoresis (2DE) and Image Acquisition. 2DE experiments were conducted as reported previously [14]. Murine GMC protein $(75 \mu \mathrm{g})$ was rehydrated overnight into IPG ( $\mathrm{pH} \mathrm{3-10;} 7 \mathrm{~cm}$; Invitrogen) strips. The strip was focused for a total of 1200-1300 Vh with a final $30 \mathrm{~min}$ focusing period at $2000 \mathrm{~V}$ constant. Proteins were separated in the second dimension on $4-12 \%$ Bis-Tris mini gels $(8 \mathrm{~cm} \times 8 \mathrm{~cm})$. The gel slabs were fixed in $10 \%$ methanol and $7 \%$ acetic acid and then transferred to SYPRO-Ruby protein gel stain (Molecular Probes, Oregon, USA) for 18 hours. Gels were scanned using a PerkinElmer ProXpress CCD-based digital imager at $50 \mu \mathrm{m}$ resolution. The gel/stain exposure and emission acquisition times were varied to maximize the detector response while avoiding detector saturation. The image files were matched, reference gels were created, and spot volumes were determined using Progenesis Discovery software (Nonlinear Dynamics, Newcastle upon Tyne, UK). A student's $t$-test is used to evaluate all matched spot pairs. Protein spots that were found to have variable spot volumes between samples were statistically compared by spot mean and SEM.

2.4. Proteomic Analyses. Protein gel spots were digested as previously described [14]. MALDI-TOF and TOF/TOF MS data were acquired on the tryptic digests using an AB4700 Proteomics Analyzer (Applied Biosystems, Foster City, CA) and analyzed using Matrix Science Mascot (ver. 2.0) as described previously [16]. Data was analyzed assuming (a) monoisotopic peptides masses, (b) cysteine carbamidomethylation, (c) variable oxidation of methionine, (d) maximum of one missed trypsin cleavage, and (e) a mass accuracy of greater than $150 \mathrm{ppm}$ for MS data and $0.3 \mathrm{Da}$ for MS-MS data against the SwissProt (release 52.0, 20070307) protein database (261513 sequences; 95638062 residues) constrained to the mammalian (50870 sequences) taxa. Limitation of the original protein mass was not employed within the Mascot search. Protein identifications were accepted for protein identifications that include using MASCOT MS +
MS/MS analysis with significant MOWSE scores $(p<0.05$; for MS MOWSE score of 60 which equals significance and for MS/MS MOWSE peptide ion score alone of 40 which equals significance).

2.5. Confocal Microscopy. Confocal microscopy images were obtained as previously described [17]. Briefly, multichambered cover glass wells (Nunc, Naperville, CT) were seeded with GMC cells. Cells were serum starved with $0.5 \%$ FBSNG medium $24 \mathrm{~h}$ before $2 \mathrm{~h}$ glucose treatment. Cells were rinsed three times with $\mathrm{PBS}$ that contained calcium and magnesium and fixed in $3.7 \%$ paraformaldehyde in PBS for $10 \mathrm{~min}$, followed by permeabilization with $0.025 \%$ NP-40 in PBS for $15 \mathrm{~min}$. Cells were incubated with primary antibody $\left(1: 250\right.$ anti-PHB in PBS/0.025\% NP-40) at $20^{\circ} \mathrm{C}$, rinsed five times with PBS/0.025\% NP-40, and incubated with the Alexa Fluor 488 conjugated secondary antibody $(1: 1000)$ at $20^{\circ} \mathrm{C}$. The cells were rinsed five times with PBS/0.025\% NP-40, incubated with $300 \mathrm{nM}$ DAPI for $5 \mathrm{~min}$, and rinsed three times with PBS. Images were acquired using a Zeiss confocal microscope and analyzed using LSM510 software. Z scan analysis was performed by scanning at $1 \mu \mathrm{m}$ intervals and three-dimensional reconstruction of the fluorescence images. The images for PHB and for DAPI were merged in a single image to elucidate PHB cellular distribution. Fluorescence intensity measurements (mean fluorescence intensity per $\mu \mathrm{m}^{2}$ ) were computed per cell ( $n=4-5$ cells per treatment replicate per treatment condition) and used to estimate differences in PHB nuclear and cytoplasmic distribution.

2.6. Protein Immunoblotting (IB). $1 \mathrm{DE}$ and $2 \mathrm{DE}$ protein immunoblots (IB) were conducted as previously described [14]. Total cell lysate samples were separated by $2 \mathrm{DE}(n=3$ $\mathrm{HG}, n=3 \mathrm{NG}^{*}$ ). For $2 \mathrm{DE} \mathrm{IB}$ analysis, following IEF of mesangial proteins, the plastic backing of the IPG strips was trimmed off. The acidic most point of the strip was aligned in the IPG well of the Bis-Tris mini gels adjacent to the MW standard lane of the minigel. This procedure insured uniform alignment of IPG strips to the MW standards, in order to compare PHB migration pattern between experimental conditions. Following 1DE or 2DE electrophoresis and transfer, membranes were immunoblotted for PHB (Santa Cruz Biotechnologies, Santa Cruz, CA) at a 1:1000 dilution in 5\% albumin in Tris-Tween-20 buffered saline (TTBS). PHB spots were imaged on film with luminol images aligned and quantified by densitometry analysis comparing the means of the acidic third and basic third of the PHB charge trains to the total train densitometry. Additional antibodies used for 1DE immunoblots were anti PDI (Stressgen; San Diego, CA) at a concentration of $1: 10,000$ and PSMA2 (Cell Signaling; Danvers, MA) at a concentration of $1: 1000$.

2.7. Analysis of Protein Expressional Networks. Ingenuity Pathways Analysis bioinformatic tool (Ingenuity Systems, Mountain View, CA) uses a curated database (Ingenuity Systems Knowledge Base) of previously published findings on mammalian biology from the public literature to evaluate proteins lists inclusive of expression ratios for protein 


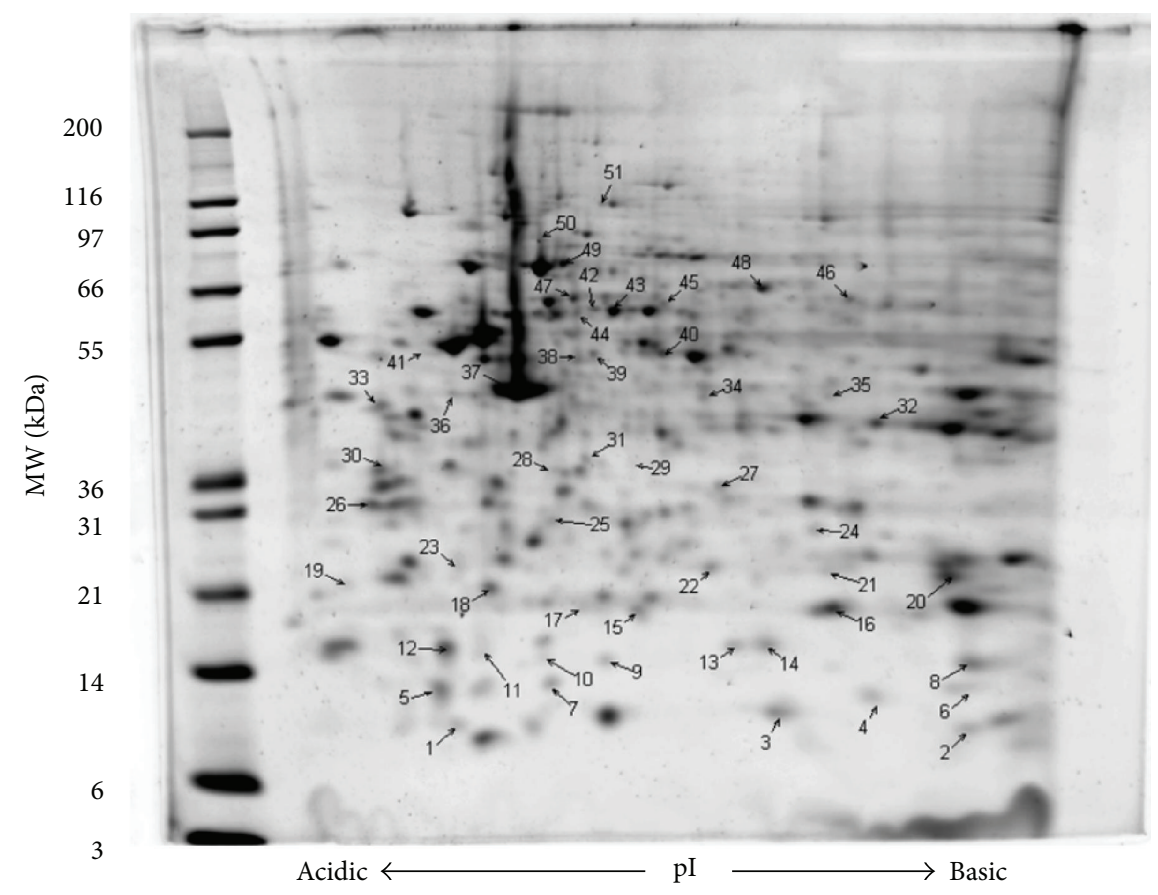

FIGURE 1: Murine GMC proteome altered by acute ( $2 \mathrm{~h}$ ) exposure to HG culture conditions. GMC cells were grown to $80 \%$ confluence and were serum-starved (0.5\% FBS) overnight, and were treated for $2 \mathrm{~h}$ with $25 \mathrm{mM}$ glucose (HG) or $5 \mathrm{mM}$ glucose $+20 \mathrm{mM}$ mannitol (NG*) as an isoosmotic control. Cells were lysed using 2DE buffer and $75 \mu \mathrm{g}$ protein used for 2DE analysis. Proteins whose expression is altered by $2 \mathrm{~h} \mathrm{HG}$ are annotated on the gel with identifications provided in Table 1. Data are representative of five individual gels for HG and for NG* conditions.

expressional patterns. The purpose of the evaluation is to establish within the lists of provided expressional data relational networks of protein interactions (e.g., direct proteinprotein interaction and transcriptional control). Analysis of submitted protein lists with expressional ratios using the Ingenuity knowledge base was used to identify direct interactions between mammalian orthologs.

Murine GMC proteins demonstrating statistically significant expression between $2 \mathrm{~h} \mathrm{HG}$ and $2 \mathrm{~h} \mathrm{NG}$ as well were analyzed by the Ingenuity Knowledge Base and Pathways Analysis tool. The data output identifies nodes characterizing individual proteins and edges characterizing biological relationships. Putative protein networks are rank ordered according to $p$ value $\left(-\log _{10} p\right)$, where the $p$ value is a measure of random association of the listed proteins.

2.8. Statistical Analysis. Statistical analysis of relative spot pixel intensity from $2 \mathrm{D}$ gels $(n=5,2 \mathrm{~h}$ each group) and analysis of PHB, PDI, or PSMA2 for HG versus $\mathrm{NG}^{*}$ expression by IB was performed using two-tailed, unpaired $t$-test. $p$ values $<0.05$ were considered significant.

\section{Results}

3.1. Alteration of Protein Expression by Acute High Glucose. Based on the MTT assay results (data not shown), GMC viability did not statistically vary between $2 \mathrm{~h}$ HG and $\mathrm{NG}^{*}$ treatments. To determine proteins regulated by $2 \mathrm{~h}$ HG treatment, protein spot volume lists were curated by first estimating intergel variability in matched protein spot volumes (averaged CV for 20 matched spots $=0.17$ ). Next, all intraglucose treatment matched gel spot volumes having a CV greater than $0.35(2 \times \mathrm{CV})$ were discarded. Fifty-one (51) protein spots had a spot volume CV of less than 0.35 and uncorrected $t$-test values of $\leq 0.05$. Thirty-five protein spots had increased expression and 16 protein spots had decreased expression with $2 \mathrm{~h}$ HG treatment and all were analyzed using proteomic methods based on MASCOT MOWSE scoring including MALDI TOF/TOF peptide fragmentation (sequence tagging) data with a significance $p$ value $\leq 0.05$ for all the reported protein identities. A representative $2 \mathrm{DE}$ gel image (with annotations) and tabulated information for 51 regulated protein spots are provided (Figure 1; Table 1). In general, all proteins identified were observed migrating in the gels at the correct molecular weight plus or minus 10\% except for gel spot 5. Cofilin-1 was identified migrating at a molecular weight of approximately $9000 \mathrm{Da}$ and a pI of 5.3. Cofilin-1 nominally has a translated molecular weight of $18,749 \mathrm{Da}$ and a $\mathrm{pI}$ of 8.2. Two additional cofilin-1 containing gel spots as well as one HSP10 containing gel spot were observed to focus on isoelectric points less than $0.5 \mathrm{pH}$ units, more acidic than expected. Twenty-three proteins were observed to focus on isoelectric points greater than $0.5 \mathrm{pH}$ units, more basic than expected. The remaining gel spots identified proteins within $0.5 \mathrm{pH}$ units of the expected $\mathrm{pI}$.

3.2. Analysis of Protein Expressional Networks. Bioinformatic analysis of protein expression in $2 \mathrm{~h} \mathrm{NG}^{*}$ versus $2 \mathrm{~h} \mathrm{HG}$ 
TABle 1

\begin{tabular}{|c|c|c|c|c|c|c|c|c|c|}
\hline \multirow{2}{*}{ Spot } & \multirow{2}{*}{ Protein name } & \multirow{2}{*}{ Gene product } & \multirow{2}{*}{$\left(\mathrm{HG} / \mathrm{NG}^{*}\right)$} & \multicolumn{2}{|c|}{ Theoretical } & \multicolumn{2}{|c|}{ Observed } & \multirow{2}{*}{ IPA network } & \multirow{2}{*}{ Percent coverage } \\
\hline & & & & $M_{r}$ & $\mathrm{pI}$ & $M_{r}$ & $\mathrm{pI}$ & & \\
\hline 1 & Not identified & & 1.23 & & & & & & \\
\hline 2 & $10 \mathrm{kDa}$ heat-shock protein, mitochondrial & CH10_RAT & 2.37 & 10895 & 8.9 & 8000 & 8.3 & $\mathrm{n} / \mathrm{a}$ & 77 \\
\hline 3 & Calpactin I light chain & S10AA_RAT & 1.37 & 11182 & 6.3 & 8000 & 7.4 & 1 & 45 \\
\hline 4 & Macrophage migration inhibitory factor & MIF_RAT & 1.34 & 12640 & 6.8 & 9000 & 7.8 & 3 & 26 \\
\hline 5 & Cofilin-1 & COF1_RAT & 1.5 & 18749 & 8.2 & 9000 & 5.3 & $\mathrm{n} / \mathrm{a}$ & 34 \\
\hline 6 & Not identified & & 1.70 & & & & & & \\
\hline 7 & Not identified & & 1.24 & & & & & & \\
\hline 8 & Profilin-1 & PROF1_RAT & 1.34 & 15119 & 8.5 & 15000 & 8.4 & 1 & 45 \\
\hline 9 & Cystatin B & CYTB_RAT & 0.82 & 11303 & 5.9 & 10000 & 6.5 & 2 & 80 \\
\hline 10 & Not identified & & 0.66 & & & & & & \\
\hline 11 & Coactosin-like protein & COTL1_MOUSE & 1.74 & 16048 & 5.3 & 16000 & 5.5 & 1,2 & 37 \\
\hline 12 & Galectin-1 & LEG1_RAT & 1.23 & 15189 & 5.1 & 15000 & 5.3 & 3 & 61 \\
\hline 13 & Histidine triad nucleotide-binding protein 1 & HINT1_MOUSE & 1.39 & 13882 & 6.4 & 11000 & 7.3 & 3 & 49 \\
\hline 14 & $40 \mathrm{~S}$ ribosomal protein $\mathrm{S} 12$ & RS12_RAT & 1.34 & 14858 & 6.8 & 15000 & 7.2 & 2 & 44 \\
\hline 15 & Nucleoside diphosphate kinase A (NDK A) & NDKA_RAT & 1.68 & 17296 & 6.0 & 16000 & 6.6 & 3 & 39 \\
\hline 16 & Nucleoside diphosphate kinase B & NDKB_RAT & 1.26 & 17386 & 6.9 & 18000 & 7.6 & 1 & 66 \\
\hline 17 & Not identified & & 1.89 & & & & & & \\
\hline \multirow[t]{2}{*}{18} & Eukaryotic translation initiation factor $5 \mathrm{~A}$ & IF5A1_RAT & 1.23 & 17049 & 5.1 & 20000 & 5.6 & 2 & 43 \\
\hline & MIR-interacting saposin-like protein & MSAP_MOUSE & & 21096 & 5.0 & 20000 & 5.6 & $\mathrm{n} / \mathrm{a}$ & 29 \\
\hline 19 & Not identified & & 1.64 & & & & & & \\
\hline 20 & Cofilin-1 & COF1_RAT & 1.63 & 18749 & 8.2 & 21000 & 8 & 1 & 65 \\
\hline 21 & Cofilin-1 & COF1_RAT & 1.59 & 18749 & 8.2 & 21000 & 7.6 & 1 & 60 \\
\hline 22 & Cofilin-1 & COF1_RAT & 1.57 & 18749 & 8.2 & 21000 & 7 & 1 & 54 \\
\hline 23 & Not identified & & 1.61 & & & & & & \\
\hline 24 & Proteasome subunit alpha type 1 & PSA2_RAT & 1.54 & 26024 & 6.9 & 23000 & 7.5 & 1 & 47 \\
\hline \multirow[t]{2}{*}{25} & Heat-shock protein beta-1 & HSPB1_RAT & 2.31 & 22936 & 6.1 & 23000 & 6.1 & 1 & 39 \\
\hline & Phosphoserine phosphatase & SERB_RAT & & 25180 & 5.5 & 23000 & 6.1 & $\mathrm{n} / \mathrm{a}$ & 33 \\
\hline 26 & 14-3-3 protein epsilon & 1433E_RAT & 1.37 & 29326 & 4.6 & 30000 & 4.8 & 1 & 29 \\
\hline 27 & Proteasome subunit alpha type 2 & PSA1_RAT & 1.78 & 29784 & 6.2 & 31000 & 7.2 & 1 & 36 \\
\hline 28 & Prohibitin & PHB_RAT & 2.24 & 29859 & 5.6 & 32000 & 6.1 & 2 & 62 \\
\hline 29 & Not identified & & 2.33 & & & & & & \\
\hline 30 & Proliferating cell nuclear antigen & PCNA_RAT & 1.46 & 29072 & 4.6 & 34000 & 4.9 & 1 & 31 \\
\hline 31 & Heat-shock protein beta-1 & HSPB1_MOUSE & 0.70 & 23057 & 6.1 & 35000 & 6.3 & $\mathrm{n} / \mathrm{a}$ & 25 \\
\hline 32 & Annexin A2 & ANXA2_RAT & 0.83 & 38939 & 7.6 & 40000 & 7.8 & 1 & 56 \\
\hline 33 & Reticulocalbin 3 precursor & RCN3_HUMAN & 1.80 & 37470 & 4.7 & 41000 & 4.9 & 2 & 20 \\
\hline 34 & Macrophage capping protein & CAPG_RAT & 1.53 & 39060 & 6.1 & 41000 & 6.9 & 3 & 20 \\
\hline 35 & Acetyl-CoA acetyltransferase, cytosolic & THIC_RAT & 2.15 & 41538 & 6.9 & 41000 & 7.7 & 3 & 28 \\
\hline 36 & SUMO-activating enzyme subunit 1 & SAE1_RAT & 2.15 & 38945 & 5.0 & 41000 & 5.4 & 2 & 54 \\
\hline \multirow[t]{2}{*}{37} & Actin, cytoplasmic-1 (beta-actin) & ACTB_RAT & 0.58 & 42052 & 5.3 & 42000 & 5.7 & 1 & 30 \\
\hline & Actin, cytoplasmic-2 (gamma-actin) & ACTG_RAT & & 42108 & 5.3 & 42000 & 5.7 & 1 & 30 \\
\hline 38 & Not identified & & 0.6 & & & & & & \\
\hline 39 & Actin-like protein 3 & ARP3_MOUSE & 0.53 & 47783 & 5.6 & 50000 & 6.5 & 1 & 38 \\
\hline \multirow[t]{2}{*}{40} & Enolase 1 & ENOA_RAT & 0.60 & 47440 & 6.2 & 52000 & 6.7 & 1 & 38 \\
\hline & RAB GDP dissociation inhibitor beta & GDIB_RAT & & 51018 & 5.9 & 52000 & 6.7 & $\mathrm{n} / \mathrm{a}$ & 34 \\
\hline 41 & Not identified & & 0.37 & & & & & & \\
\hline 42 & Not identified & & 0.71 & & & & & & \\
\hline 43 & Protein disulfide-isomerase A3 (ERp57) & PDIA3_RAT & 0.78 & 57044 & 5.9 & 58000 & 6.4 & 3 & 50 \\
\hline 44 & GRP58 & HNRPK_RAT & 0.68 & 51230 & 5.4 & 57000 & 6.3 & 1 & 31 \\
\hline 45 & Not identified & & 2.21 & & & & & & \\
\hline 46 & Heterogeneous nuclear ribonucleoprotein L & HNRPL_MOUSE & 1.40 & 60712 & 6.7 & 58000 & 7.8 & 2 & 25 \\
\hline 47 & T-complex protein 1, epsilon subunit & TCPE_RAT & 0.78 & 59955 & 5.5 & 58000 & 6.3 & 1 & 34 \\
\hline
\end{tabular}


TABle 1: Continued.

\begin{tabular}{|c|c|c|c|c|c|c|c|c|c|}
\hline \multirow{2}{*}{ Spot } & \multirow{2}{*}{ Protein name } & \multirow{2}{*}{ Gene product } & \multirow{2}{*}{$\left(\mathrm{HG} / \mathrm{NG}^{*}\right)$} & \multicolumn{2}{|c|}{ Theoretical } & \multicolumn{2}{|c|}{ Observed } & \multirow{2}{*}{ IPA network } & \multirow{2}{*}{ Percent coverage } \\
\hline & & & & $M_{r}$ & $\mathrm{pI}$ & $M_{r}$ & $\mathrm{pI}$ & & \\
\hline 48 & Hsc70/Hsp90-organizing protein & STIP1_RAT & 1.16 & 63158 & 6.4 & 65000 & 7.2 & 1 & 38 \\
\hline 49 & GRP 75 & GRP75_RAT & 0.82 & 74097 & 6.0 & 75000 & 6.1 & 1 & 31 \\
\hline 50 & Not identified & & 1.35 & & & & & & \\
\hline 51 & RAB 6 interacting protein 2 (ERC protein 1$)$ & GANAB_MOUSE & 0.68 & 107300 & 5.7 & 116000 & 6.4 & 2 & 21 \\
\hline
\end{tabular}

Murine GMC protein expression at $2 \mathrm{~h}$ culture $\mathrm{HG}$ versus $2 \mathrm{~h}$ culture $\mathrm{NG}^{*}$.

was achieved using the Ingenuity Knowledge Base and Pathways Analysis tools. The top three canonical pathways determined to be activated from $2 \mathrm{~h}$ acute high glucose exposure were actin-based motility by Rho, RhoA signaling, and the protein ubiquitination pathway. Analysis of protein expressional networks from murine GMC $2 \mathrm{~h} \mathrm{NG}{ }^{*}$ and $2 \mathrm{~h}$ HG protein expressional data suggested three primary expression networks. Network 1 (score 49) addressed cancer, reproductive system disease, and hematological disease and included 25 identified proteins out of 35 total network components (Figure 2(a)). Network 2 (score 19) addressed cell death and survival, drug metabolism, and lipid metabolism and included 9 identified proteins out of 35 protein nodes (Figure 2(b)). Network 3 (score 14) addressed cellular movement, cellular compromise, cellular function, and maintenance and was composed of 7 identified proteins out of 29 possible network proteins. Prominent nodes within Network 1 were centered on signaling proteins including proteins involved with ubiquitination, cyclin D, ERK1/ERK2 MAPKinase, HSP90, ROCK, and histones h3 and h4. Prominent nodes in network 2 were centered on the VEGF, TNF, TGF $\beta 1$, tumor protein 53 (TP53), and ubiquitination.

\subsection{Immunochemical Analysis for the Effect of High Glucose} on the Expression of Proteins. Immunoblot (IB) analyses of the selected proteins were used to confirm the 2DE findings. Prohibitin (PHB) was selected for confirmation as it was one of the most strongly regulated protein spots and was also a component of IPA Network 2 with direct interaction with a prominent network node of TNF. The expression by 1DE (Figures 3(a) and 3(b)) supported a trend in increased total PHB abundance, but 2DE IB analysis of $2 \mathrm{~h} \mathrm{GMC} \mathrm{cells}$ cultured in $\mathrm{HG}$ and $\mathrm{NG}^{*}$ showed a $\mathrm{HG}$ responsive and statistically significant $(p<0.02)$ increase in the acidic end of the PHB charge train (Figure 4). Confocal microscopy (Figures 5(a) and 5(b)) suggested that high glucose resulted in a statistically significant $(p$ value $<0.0001)$ increased fractional abundance of PHB in the nucleus of the GMC.

Based on bioinformatics analysis defining regulation of protein ubiquitination pathways in one of the top three canonical pathways regulated, as well as a prominent node in protein expression Networks 1 and 2, we next analyzed the expression of proteins involved in protein homeostasis and found them to be regulated by $2 \mathrm{DE}$ analysis. Proteasome subunit alpha-type 2 (PSMA2) was confirmed to be increased in mesangial cells exposed to high glucose concentrations for $2 \mathrm{~h}$ (Figure 6). Comparative 2DE analysis also defined decreased expression of ER chaperone proteins such as PDI and GRP58, which may lead to increased unfolded protein load in mesangial cells and induction of proteasomal degradation processes. Immunoblot analysis of mesangial proteins for PDI confirmed 2DE findings of decreased expression of PDI (Figure 6).

\section{Discussion}

GMCs participate in glomerular growth and differentiation as well as in regulation of glomerular blood flow [3,4]. It is well established that chronic hyperglycemia such as in an uncontrolled diabetic state detrimentally affects the renal glomerulus and produces a pathologic GMC phenotype [18-22]. On the other hand, a gap in knowledge exists for changes in GMC function and protein expression patterns which occur in individuals who experience longer postprandial elevated plasma glucose levels [23]. Therefore to ascertain the effects of short term high glucose conditions encountered by GMC in subpathologic/prediabetic states, we conducted proteomic studies comparing mesangial protein expression after $2 \mathrm{~h} \mathrm{HG}$ conditions against mesangial protein expression after $2 \mathrm{~h} \mathrm{NG}^{*}$ growth conditions. The analysis of cell viability at $2 \mathrm{~h}$ in the treatment conditions determined that mesangial cell viability was not decreased by the treatment conditions and time. The protein expression differences observed between the growth conditions were not therefore attributed to variable degrees of cell proliferation. Expressional regulation of 51 identified protein spots were observed under the conditions of $2 \mathrm{~h} \mathrm{HG}$. These proteins can be grouped as follows: cytoskeletal proteins, calcium/phospholipid binding proteins, chaperones, and proliferation and signaling-related proteins.

Increased glucose levels are known to stimulate a variety of responses within GMC including remodeling of cytoskeletal elements like actin and actin binding proteins [24]. Two upregulated spots were identified as cofilin-1 and cofilin-2 and demonstrated a $55-60 \%$ increased expression. Cofilins are actin binding proteins that affect the mobility of actin monomers at the ends of actively growing actin filaments and increase actin filament turnover. Cofilins bind and sever the pointed actin ends and increase the actin monomer pool. During conditions of stress, cofilins participate in the nuclear import of actin [24]. Two protein spots demonstrating reduced expression by HG, identified as the actin capping proteins, F-actin capping protein $\beta$-subunit, and actin-like protein 3 . Each of these proteins migrated at the expected $M_{r}$ and pI. These proteins, respectively, demonstrated a $30 \%$ and $50 \%$ decreased presence in the $2 \mathrm{DE}$ gels. 


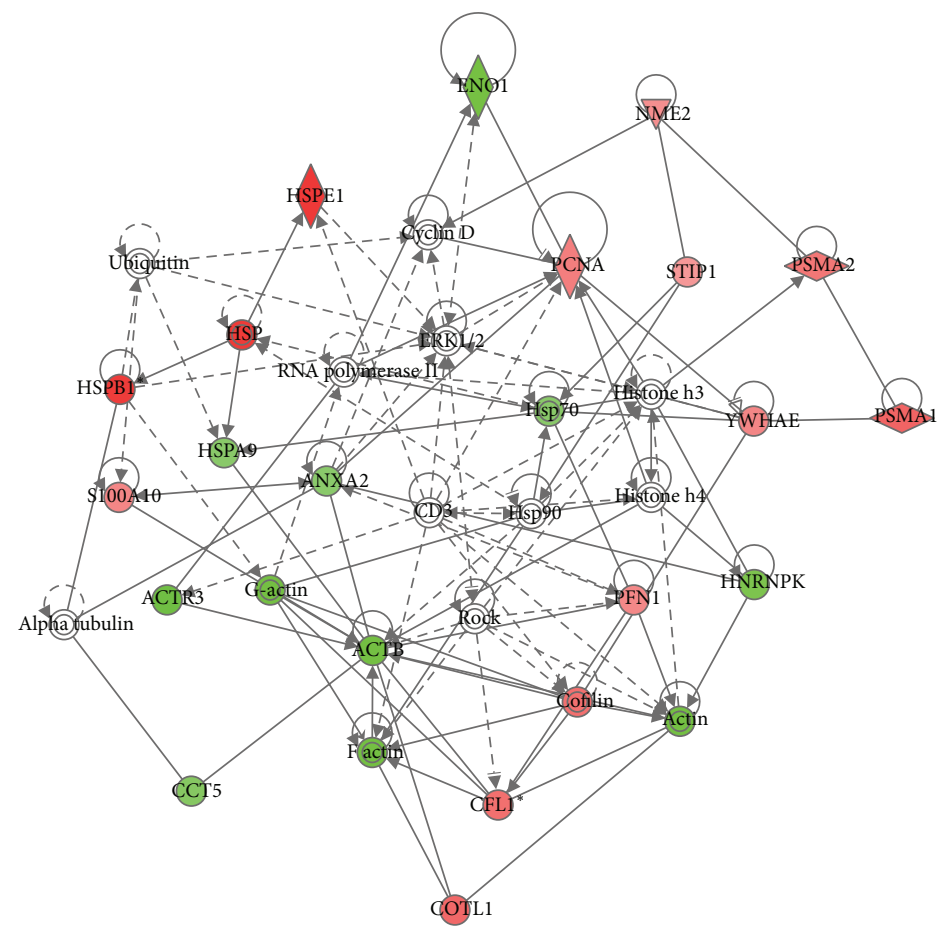

(a)

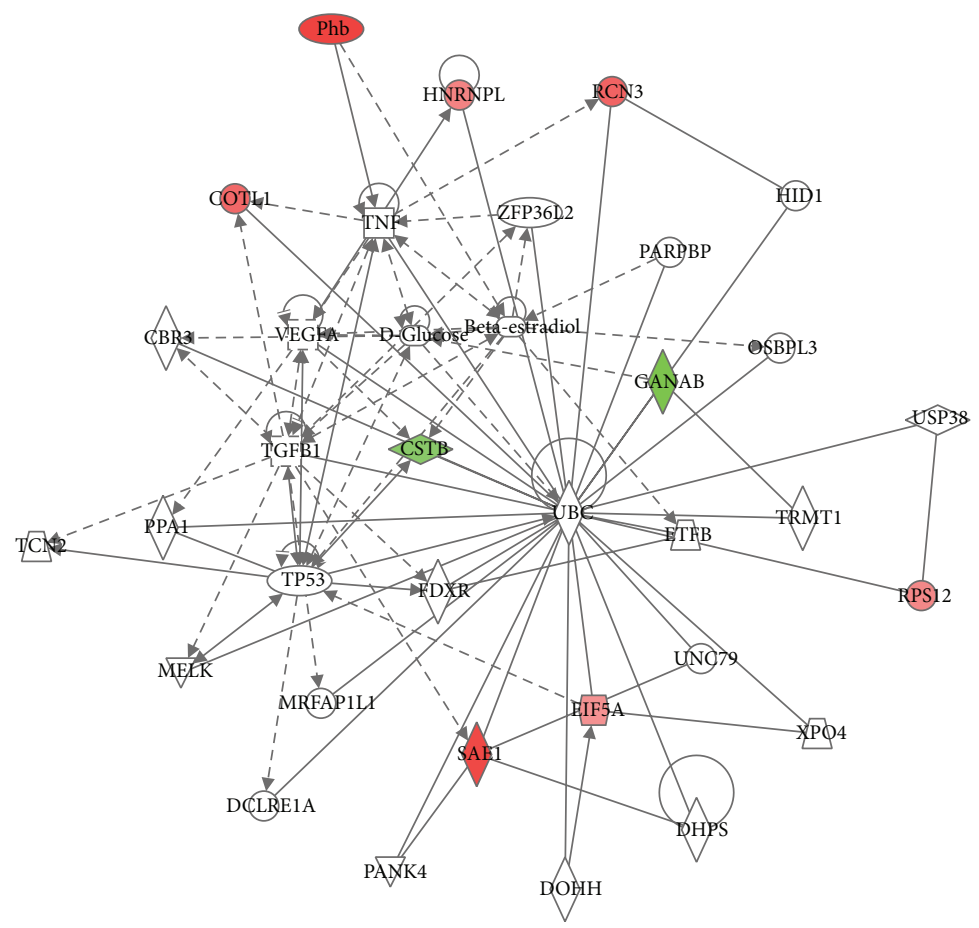

(b)

Figure 2: Network analysis of protein expression patterns using Ingenuity Pathways Analysis. (a) The top scoring network (Network 1) addressed cancer, reproductive system disease, and hematological disease and included 25 identified proteins out of 35 total network components. The score 49 suggests the odds of 1 out of $10^{49}$ for assembling randomly these protein identifications out of the existing murine protein database. (b) Network 2, defined by IPA, includes PHB. For (a) and (b), red indicates protein spots whose spot volume increased with $2 \mathrm{~h}$ high glucose. Green indicates proteins spots whose spot volume decreased with $2 \mathrm{~h}$ high glucose. 


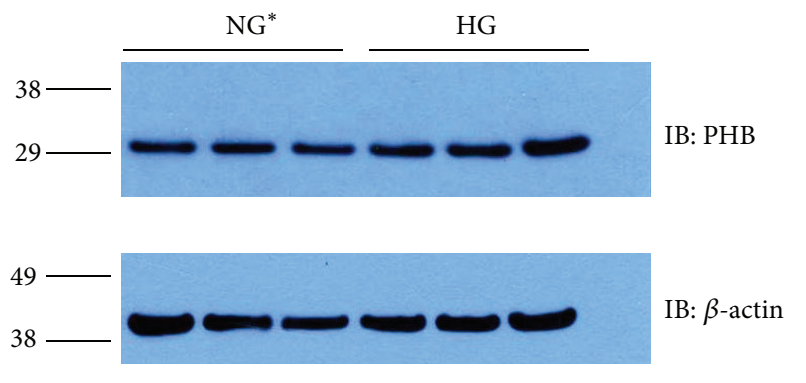

(a)

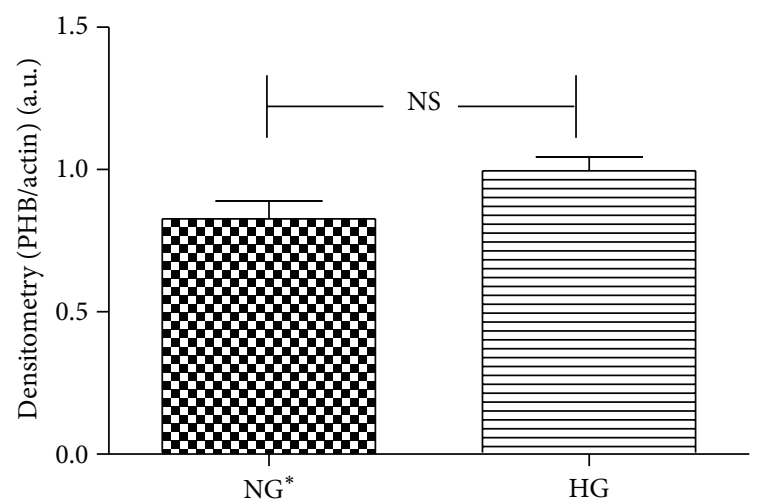

(b)

FIGURE 3: Validation of 2DE results for the enhanced PHB expression. Murine GMCs were cultured and treated for $2 \mathrm{~h}$ with HG and NG* as described. Cells were lysed in 2DE buffer, diluted into Laemmli buffer, and used for immunoblot experiments (a) and quantification of 1DE IB experiments for PHB expression normalized to total actin expression (b). Data is presented as a mean of three experiments. Statistical analysis of differences between the means of $\mathrm{HG}$ and $\mathrm{NG}^{*}$ was achieved by $t$-test.
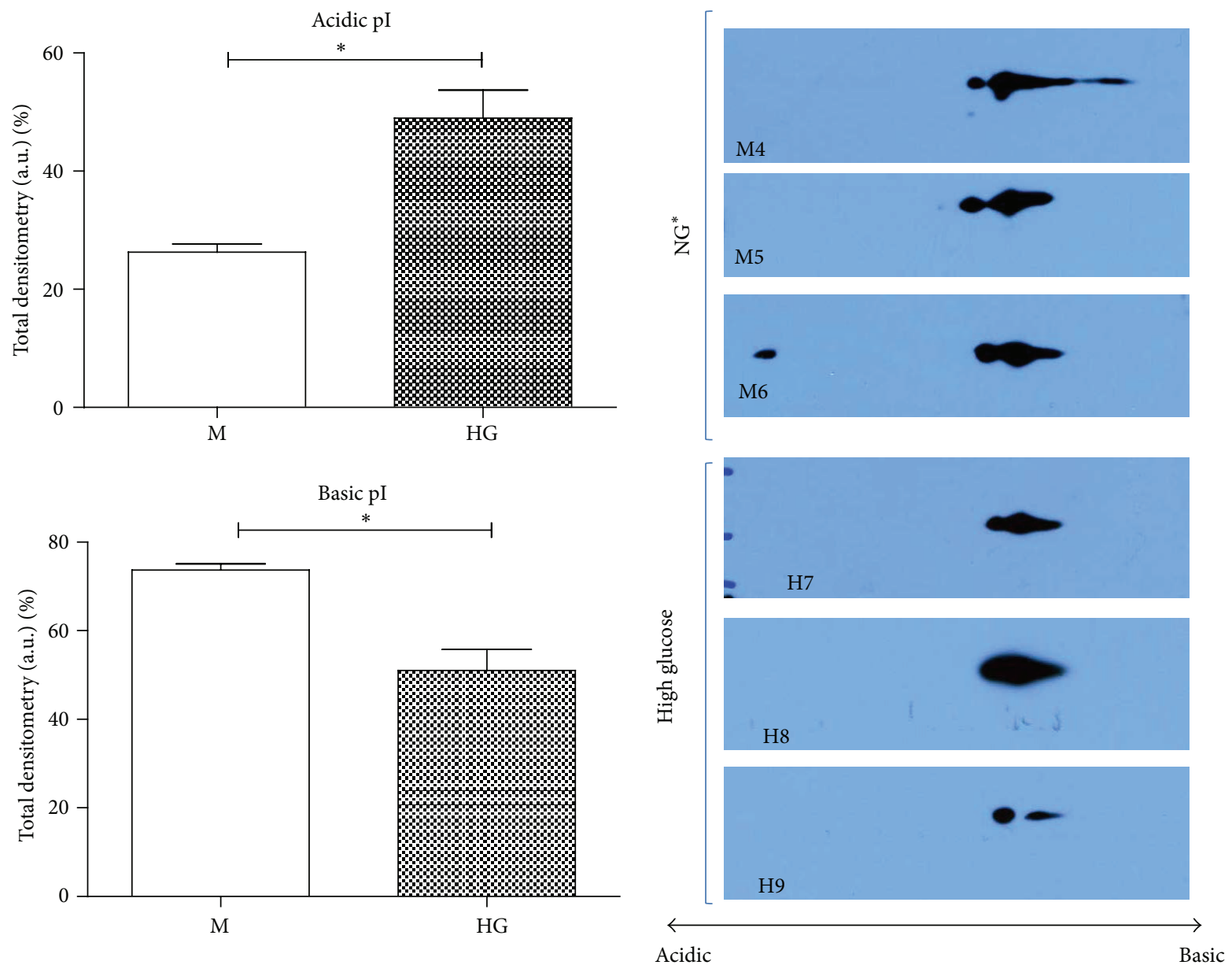

FIGURE 4: 2DE immunoblot experiments were used to determine the effects of $\mathrm{HG}$ and $\mathrm{NG}^{*}$ on PHB isoforms. Following the transfer and development of PHB IB, images were aligned and densitometric measurements were estimated using ImageJ for the acidic one-third of the PHB charge train and for the basic two-thirds of the PHB charge train (IB images on right). Fractional values for PHB charge train components (acid and basic ends) were used to determine statistical significance differences (left bar graphs). $\mathrm{M}$ is the same as $\mathrm{NG}^{*}$ (5 $\mathrm{mM} \mathrm{D}^{-g l u c o s e}+$ mannitol); HG is $25 \mathrm{mM} \mathrm{D}$-glucose. ${ }^{*} p$ value $<0.01$. 

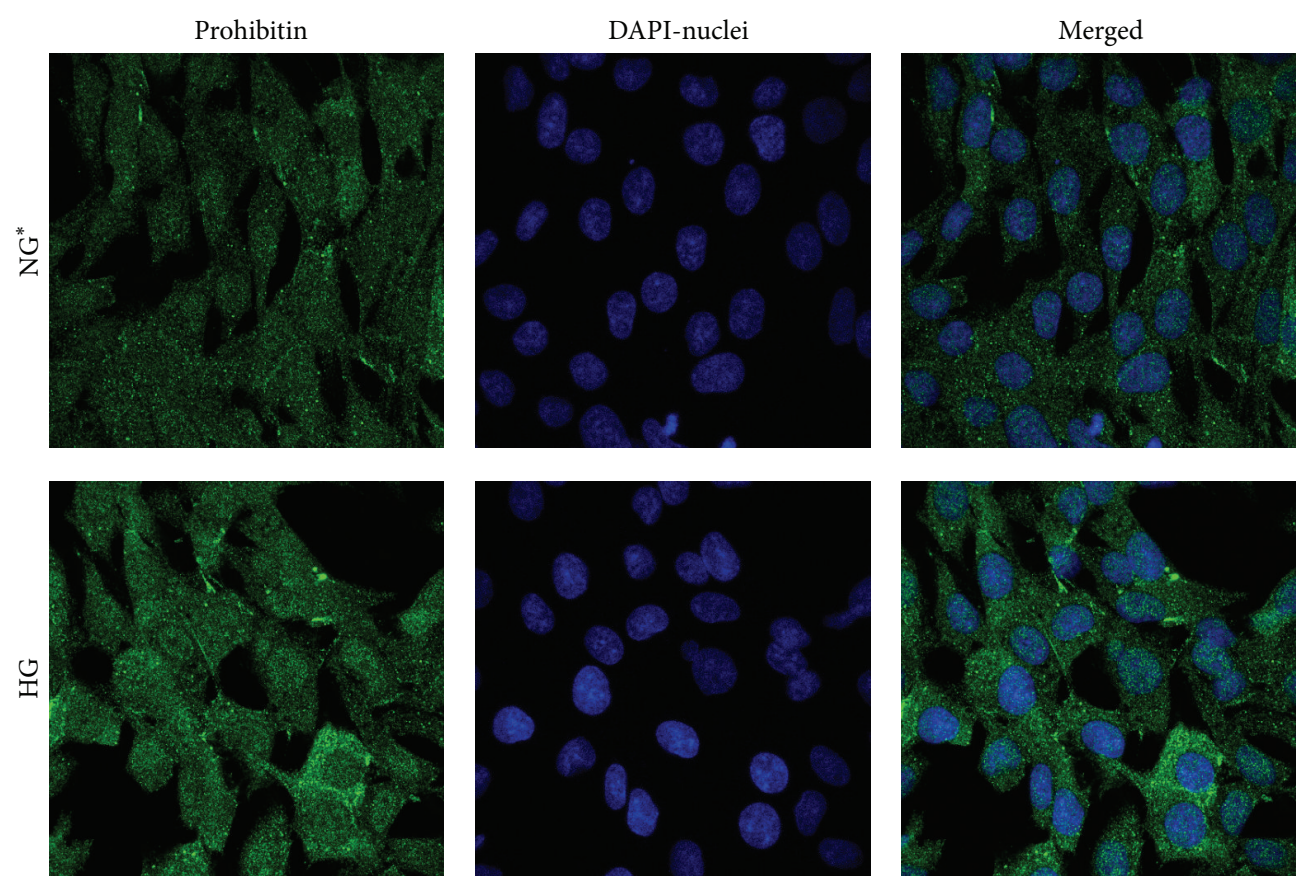

(a)

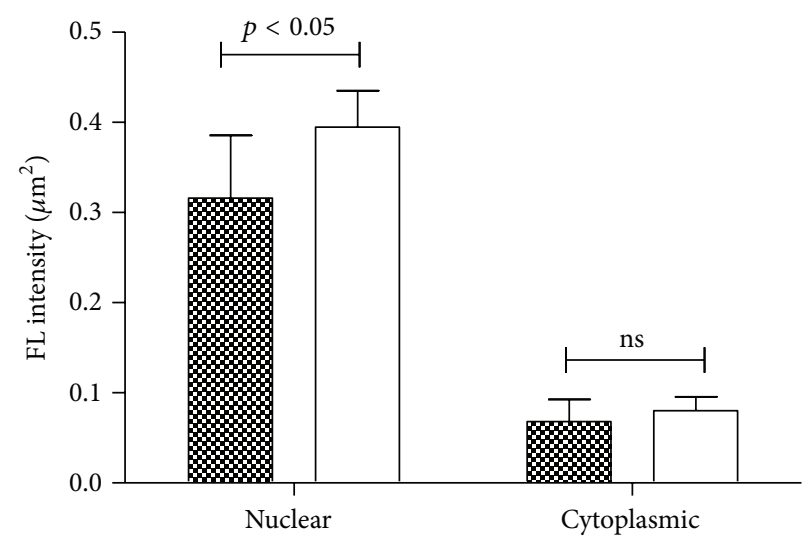

\$\% LG + mannitol

HG

(b)

Figure 5: (a) Murine GMCs were seeded into 8-well chambered cover glass, grown, and treated as described in the methods. PHB detection was with the same primary antibody as used for IB. PHB detection with an Alexa Fluor 488 conjugated secondary antibody (green). Nuclei were stained with DAPI (blue). Confocal software was used to estimate pixel density in GMC and in nuclei (as defined by DAPI). Nuclei pixel density was subtracted from total density and plotted (b). Differences were estimated by $t$-test with significance at $p$ value $<0.05$.

Additionally, an acidic isoform of the intermediate filament protein vimentin was downregulated.

Calpactin light chain (also referred to as S100A10 or p11) functions as a ligand of annexin II (annexin $\mathrm{II}_{2}:$ p $11_{2}$ ) [2527]. Calpactin and annexin II were shown here to be upregulated by approximately $37 \%$ and $23 \%$, respectively by acute hyperglycemic conditions. Calpactin complexed to annexin II is known to interact with the C-terminus of cytosolic phospholipase A2 and inhibits CPLA2 activity thus reducing inflammatory responses from the release of arachidonic acid [28]. Upregulation of reticulocalbindin 3 is necessary for increased sequestration of $\mathrm{Ca}^{2+}$. The increased $\mathrm{Ca}^{2+}$ is in turn needed by other proteins found in the reticuloplasm like GRP78 or PDIA3 [29]. These observations of regulated changes in actin cytoskeletal protein and calcium binding protein expression, when taken together, are consistent with the known responses of mesangial cells to HG under more chronic conditions [30,31].

Molecular chaperones have been well described in the literature as protein quality control managers that assist with the maintenance of cellular function in the face of stress conditions like heat stress, osmotic stress, or oxidant 

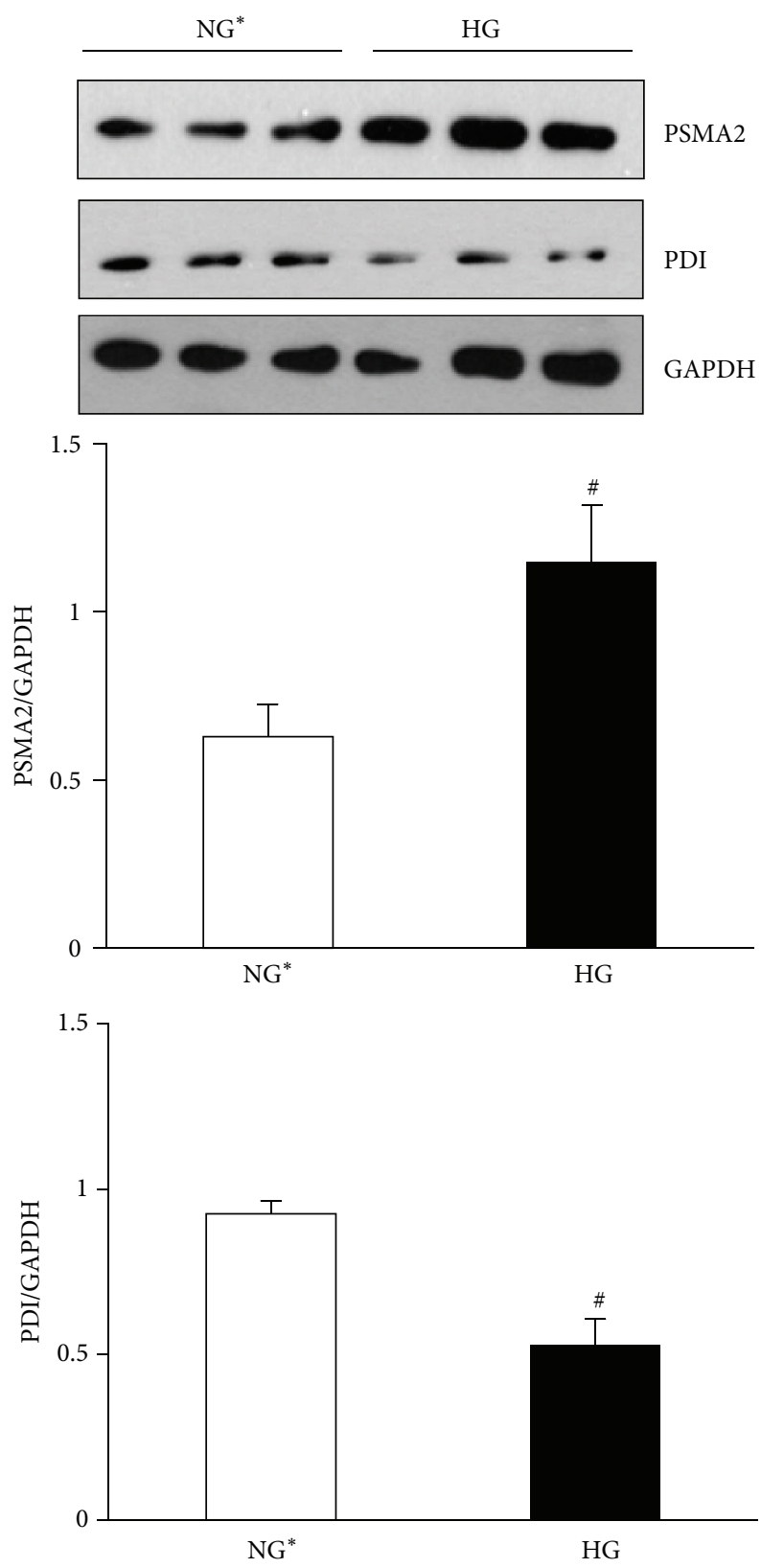

FIGURE 6: Correlative validation of 2DE results for the regulation of pathways involved in proteostasis. Immunoblot analysis of PSMA2 and PDI from mesangial cells cultured for $2 \mathrm{~h}$ in $\mathrm{HG}$ or $\mathrm{NG}^{*}$ medium. Expression of PSMA2 increased whereas PDI decreased following $2 \mathrm{~h} \mathrm{HG}$. Bar graphs, densitometric quantitation of PSMA2 or PDI normalized to GAPDH for each lane. Data are average \pm SEM ${ }^{\#} p<0.05$ versus $\mathrm{NG}^{*}$.

stress. Specific chaperones are spatially organized throughout the cell via organellar localization $[32,33]$. The bulk of all mitochondrial proteins are synthesized under the direction of cell nuclear transcripts in the cytoplasm [34]. High molecular weight proteins are trafficked through and between the mitochondrial membranes and into mitochondrial matrix and require protein folding chaperone such as PHB and HSP10 for efficient protein folding [35]. A protein spot containing
PHB, possibly a posttranslationally modified form causing an acidic shift in PHB pI, was found to exhibit expressional regulation by $2 \mathrm{DE}, 2 \mathrm{DE} \mathrm{IB}$ and increased nuclear localization by confocal microscopy analysis, following acute $(2 \mathrm{~h})$ glucose exposure in GMCs. PHB has been reported to exist as a membrane resident chaperone that participates in the protein folding pathway of mitochondrial-derived integral membrane proteins like COX $2 p$ and COX $3 p$. Moreover, movement of PHB between the mitochondria and nucleus has been shown to play an important role in signaling mitochondrial oxidant stress and regulating apoptosis and transcription during stress, highlighting the importance of this protein to mitochondrial-nuclear communication [36, 37]. In the current study, observations of increased acidic forms of $\mathrm{PHB}$, increased PHB nuclear localization, increased HSP10, and decreased GRP75 at $2 \mathrm{~h} \mathrm{HG}$ stimulation suggest that acute hyperglycemic conditions may promote proteinstructural stress within the mitochondrial matrix promoting translocation of PHB to the nucleus for an as-of-yet determined reason in GMCs. In addition, bioinformatic analysis grouped $\mathrm{PHB}$ and additional proteins regulated by $2 \mathrm{~h} \mathrm{HG}$ in a network including mediators known to be involved in the pathogenesis of diabetic nephropathy and fibrosis, such as TGF $\beta$, VEGF, and TNF $[1,38]$, highlighting a potentially novel role for PHB in GMC responses to HG.

One aspect of cell cycle control is polyubiquitination of cytoplasmic or nuclear proteins [39]. Polyubiquitination is a trigger for the trafficking of the modified protein to the proteasome for degradation. A second aspect of cell cycle control is exercised through monoubiquitination of nuclear proteins like histones [40-42]. Our observations with increased expression of PSMA2 are specific to acute exposure of cells to medium containing high glucose as compared to isoosmotic low glucose medium and suggest the likelihood of increased proteasomal activity. These findings are in part supported by the observations of decreased ubiquitinated cytosolic proteins in mesangial cells with $2 \mathrm{~h}$ high glucose concentrations (data not shown). Together, increased expression of PSMA2 and decreased expression of PDI with acute exposure to high glucose concentrations suggest regulation of pathways involved in proteostasis and/or cell stress response. In the ER, PDI serves an oxidoreductase chaperone regulating disulfide bonds [43] and its activity is decreased in liver cells of diabetic mice [44]. Furthermore, kidneys and liver of diabetic mice also have decreased expression of PDI $[45,46]$. Decreased expression of PDI in response to high glucose may alter protein maturation in the ER, triggering a stress response which includes increased protein degradation by the proteasome. The mechanism of decreased PDI expression in mesangial cells by acute exposure to high glucose remains to be defined.

In conclusion, the proteomics data and bioinformatic data analysis suggests that murine GMCs respond to acute $\mathrm{HG}$ via expression of proteins related by pathways regulating protein posttranslational modification and protein stability. These acute differences may also be important for cellular function as reported for GMCs treated with longer more chronic hyperglycemic time points of differences in specific protein abundance such as enolase, actin, and annexin proteins [30]. 


\section{Conflict of Interests}

The authors have no conflict of interests to disclose.

\section{Acknowledgment}

The authors would like to acknowledge the support of the funding from the National Institutes of Health K01-DK080951 to Michelle T. Barati.

\section{References}

[1] S. Chen, M. P. Cohen, G. T. Lautenslager, C. W. Shearman, and F. N. Ziyadeh, "Glycated albumin stimulates TGF-beta 1 production and protein kinase $\mathrm{C}$ activity in glomerular endothelial cells," Kidney International, vol. 59, no. 2, pp. 673681, 2001.

[2] D. W. Powell, R. C. Mifflin, J. D. Valentich, S. E. Crowe, J. I. Saada, and A. B. West, "Myofibroblasts. I. Paracrine cells important in health and disease," American Journal of Physiology-Cell Physiology, vol. 277, no. 1, pp. C1-C9, 1999.

[3] J. E. B. Reusch, "Diabetes, microvascular complications, and cardiovascular complications: what is it about glucose?" Journal of Clinical Investigation, vol. 112, no. 7, pp. 986-988, 2003.

[4] J. D. Stockand and S. C. Sansom, "Glomerular mesangial cells: electrophysiology and regulation of contraction," Physiological Reviews, vol. 78, no. 3, pp. 723-744, 1998.

[5] S. L. Carney, N. L. M. Wong, and J. H. Dirks, "Acute effects of streptozotocin diabetes on rat renal function," Journal of Laboratory and Clinical Medicine, vol. 93, no. 6, pp. 950-961, 1979.

[6] J. S. Christiansen, J. Gammelgaard, M. Frandsen, and H.-H. Parving, "Increased kidney size, glomerular filtration rate and renal plasma flow in short-term insulin-dependent diabetics," Diabetologia, vol. 20, no. 4, pp. 451-456, 1981.

[7] T. H. Hostetter, H. G. Rennke, and B. M. Brenner, "The case for intrarenal hypertension in the initiation and progression of diabetic and other glomerulopathies," The American Journal of Medicine, vol. 72, no. 3, pp. 375-380, 1982.

[8] S. Stackhouse, P. L. Miller, S. K. Park, and T. W. Meyer, "Reversal of glomerular hyperfiltration and renal hypertrophy by blood glucose normalization in diabetic rats," Diabetes, vol. 39 , no. 8 , pp. 989-995, 1990.

[9] G. Stalder and R. Schmid, "Severe functional disorders of glomerular capillaries and renal hemodynamics in treated diabetes mellitus during childhood," Annales Paediatrici, vol. 193, pp. 129-138, 1959.

[10] R. Zatz, T. W. Meyer, H. G. Rennke, and B. M. Brenner, "Predominance of hemodynamic rather than metabolic factors in the pathogenesis of diabetic glomerulopathy," Proceedings of the National Academy of Sciences of the United States of America, vol. 82, no. 17, pp. 5963-5967, 1985.

[11] M. Brownlee, "Biochemistry and molecular cell biology of diabetic complications," Nature, vol. 414, no. 6865, pp. 813-820, 2001.

[12] M. Brownlee, "The pathobiology of diabetic complications: a unifying mechanism," Diabetes, vol. 54, no. 6, pp. 1615-1625, 2005.

[13] F. P. Schena and L. Gesualdo, "Pathogenetic mechanisms of diabetic nephropathy," Journal of the American Society of Nephrology, vol. 16, supplement 1, pp. S30-S33, 2005.
[14] M. T. Barati, M. L. Merchant, A. B. Kain, A. W. Jevans, K. R. McLeish, and J. B. Klein, "Proteomic analysis defines altered cellular redox pathways and advanced glycation end-product metabolism in glomeruli of $\mathrm{db} / \mathrm{db}$ diabetic mice," American Journal of Physiology-Renal Physiology, vol. 293, no. 4, pp. F1157-F1165, 2007.

[15] T. Mosmann, "Rapid colorimetric assay for cellular growth and survival: application to proliferation and cytotoxicity assays," Journal of Immunological Methods, vol. 65, no. 1-2, pp. 55-63, 1983.

[16] C. Smith, M. Merchant, A. Fekete et al., "Splice variants of neuronal nitric oxide synthase are present in the rat kidney," Nephrology Dialysis Transplantation, vol. 24, no. 5, pp. 14221428, 2009.

[17] M. L. Merchant, B. A. Perkins, G. M. Boratyn et al., "Urinary peptidome may predict renal function decline in type 1 diabetes and microalbuminuria," Journal of the American Society of Nephrology, vol. 20, no. 9, pp. 2065-2074, 2009.

[18] M. E. Cooper, "Interaction of metabolic and haemodynamic factors in mediating experimental diabetic nephropathy," Diabetologia, vol. 44, no. 11, pp. 1957-1972, 2001.

[19] R. M. Mason and N. A. Wahab, "Extracellular matrix metabolism in diabetic nephropathy," Journal of the American Society of Nephrology, vol. 14, no. 5, pp. 1358-1373, 2003.

[20] T. Nishikawa, D. Edelstein, and M. Brownlee, "The missing link: a single unifying mechanism for diabetic complications," Kidney International, Supplement, vol. 58, pp. S26-S30, 2000.

[21] N. A. Wahab, K. Harper, and R. M. Mason, "Expression of extracellular matrix molecules in human mesangial cells in response to prolonged hyperglycaemia," Biochemical Journal, vol. 316, no. 3, pp. 985-992, 1996.

[22] G. Wolf, "New insights into the pathophysiology of diabetic nephropathy: from haemodynamics to molecular pathology," European Journal of Clinical Investigation, vol. 34, no. 12, pp. 785-796, 2004.

[23] J. Fan, S. J. May, Y. Zhou, and E. Barrett-Connor, "Bimodality of 2-h plasma glucose distributions in whites: the Rancho Bernardo study," Diabetes Care, vol. 28, no. 6, pp. 1451-1456, 2005.

[24] M. R. Clarkson, M. Murphy, S. Gupta et al., "High glucosealtered gene expression in mesangial cells. Actin-regulatory protein gene expression is triggered by oxidative stress and cytoskeletal disassembly," The Journal of Biological Chemistry, vol. 277, pp. 9707-9712, 2002.

[25] R. Bianchi, G. Pula, P. Ceccarelli, I. Giambanco, and R. Donato, "S-100 protein binds to annexin II and p11, the heavy and light chains of calpactin I," Biochimica et Biophysica Acta (BBA)Protein Structure and Molecular Enzymology, vol. 1160, no. 1, pp. 67-75, 1992.

[26] Y. Miura, M. Kano, K. Abe, S. Urano, S. Suzuki, and T. Toda, "Age-dependent variations of cell response to oxidative stress: proteomic approach to protein expression and phosphorylation," Electrophoresis, vol. 26, no. 14, pp. 2786-2796, 2005.

[27] S. Réty, J. Sopkova, M. Renouard et al., "The crystal structure of a complex of p11 with the annexin II N-terminal peptide," Nature Structural Biology, vol. 6, no. 1, pp. 89-95, 1999.

[28] L. Parente and E. Solito, "Annexin 1: more than an antiphospholipase protein," Inflammation Research, vol. 53, no. 4, pp. 125-132, 2004.

[29] D. Burdakov, O. H. Petersen, and A. Verkhratsky, "Intraluminal calcium as a primary regulator of endoplasmic reticulum function," Cell Calcium, vol. 38, no. 3-4, pp. 303-310, 2005. 
[30] S. P. Ramachandra Rao, R. Wassel, M. A. Shaw, and K. Sharma, "Profiling of human mesangial cell subproteomes reveals a role for calmodulin in glucose uptake," American Journal of Physiology-Renal Physiology, vol. 292, no. 4, pp. F1182-F1189, 2007.

[31] C. Whiteside, S. Munk, E. Ispanovic et al., "Regulation of mesangial cell alpha-smooth muscle actin expression in 3dimensional matrix by high glucose and growth factors," Nephron Experimental Nephrology, vol. 109, no. 2, pp. e46-e56, 2008.

[32] F.-X. Beck, R. Grünbein, K. Lugmayr, and W. Neuhofer, "Heat shock proteins and the cellular response to osmotic stress," Cellular Physiology and Biochemistry, vol. 10, no. 5-6, pp. 303306, 2000.

[33] F.-X. Beck, W. Neuhofer, and E. Müller, "Molecular chaperones in the kidney: distribution, putative roles, and regulation," The American Journal of Physiology-Renal Physiology, vol. 279, no. 2, pp. F203-F215, 2000.

[34] J. M. Herrmann and K. Hell, "Chopped, trapped or tackedprotein translocation into the IMS of mitochondria," Trends in Biochemical Sciences, vol. 30, no. 4, pp. 205-212, 2005.

[35] L. G. J. Nijtmans, L. De Jong, M. A. Sanz et al., "Prohibitins act as a membrane-bound chaperone for the stabilization of mitochondrial proteins," The EMBO Journal, vol. 19, no. 11, pp. 2444-2451, 2000.

[36] A. S. Kathiria, M. A. Butcher, J. M. Hansen, and A. L. Theiss, "Nrf2 is not required for epithelial prohibitin-dependent attenuation of experimental colitis," American Journal of Physiology-Gastrointestinal and Liver Physiology, vol. 304, no. 10, pp. G885-G896, 2013.

[37] S. R. Sripathi, W. He, C. L. Atkinson et al., "Mitochondrialnuclear communication by prohibitin shuttling under oxidative stress," Biochemistry, vol. 50, no. 39, pp. 8342-8351, 2011.

[38] Y.-J. Liang, J.-H. Jian, Y.-C. Liu et al., "Advanced glycation end products-induced apoptosis attenuated by PPARdelta activation and epigallocatechin gallate through NF-kappaB pathway in human embryonic kidney cells and human mesangial cells," Diabetes/Metabolism Research and Reviews, vol. 26, no. 5, pp. 406-416, 2010.

[39] O. Kerscher, R. Felberbaum, and M. Hochstrasser, "Modification of proteins by ubiquitin and ubiquitin-like proteins," Annual Review of Cell and Developmental Biology, vol. 22, pp. 159-180, 2006

[40] C.-F. Kao, C. Hillyer, T. Tsukuda, K. Henry, S. Berger, and M. A. Osley, "Rad6 plays a role in transcriptional activation through ubiquitylation of histone H2B," Genes \& Development, vol. 18, no. 2, pp. 184-195, 2004.

[41] J. C. Tanny, H. Erdjument-Bromage, P. Tempst, and C. D. Allis, "Ubiquitylation of histone $\mathrm{H} 2 \mathrm{~B}$ controls RNA polymerase II transcription elongation independently of histone $\mathrm{H} 3$ methylation," Genes \& Development, vol. 21, no. 7, pp. 835-847, 2007.

[42] P. Zhu, W. Zhou, J. Wang et al., "A histone H2A deubiquitinase complex coordinating histone acetylation and $\mathrm{H} 1$ dissociation in transcriptional regulation," Molecular Cell, vol. 27, no. 4, pp. 609-621, 2007.

[43] F. R. M. Laurindo, L. A. Pescatore, and D. de Castro Fernandes, "Protein disulfide isomerase in redox cell signaling and homeostasis," Free Radical Biology and Medicine, vol. 52, no. 9, pp. 1954-1969, 2012.
[44] G. Nardai, K. Stadler, E. Papp, T. Korcsmáros, J. Jakus, and P. Csermely, "Diabetic changes in the redox status of the microsomal protein folding machinery," Biochemical and Biophysical Research Communications, vol. 334, no. 3, pp. 787-795, 2005.

[45] M. T. Barati, D. W. Powell, B. D. Kechavarzi et al., "Differential expression of endoplasmic reticulum stress-response proteins in different renal tubule subtypes of OVE26 diabetic mice," Cell Stress and Chaperones, 2015.

[46] N. Yamagishi, T. Ueda, A. Mori, Y. Saito, and T. Hatayama, "Decreased expression of endoplasmic reticulum chaperone GRP78 in liver of diabetic mice," Biochemical and Biophysical Research Communications, vol. 417, no. 1, pp. 364-370, 2012. 


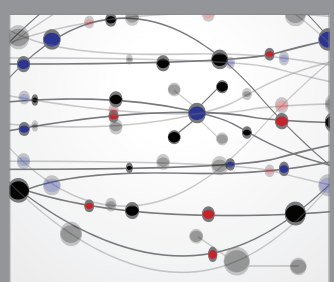

The Scientific World Journal
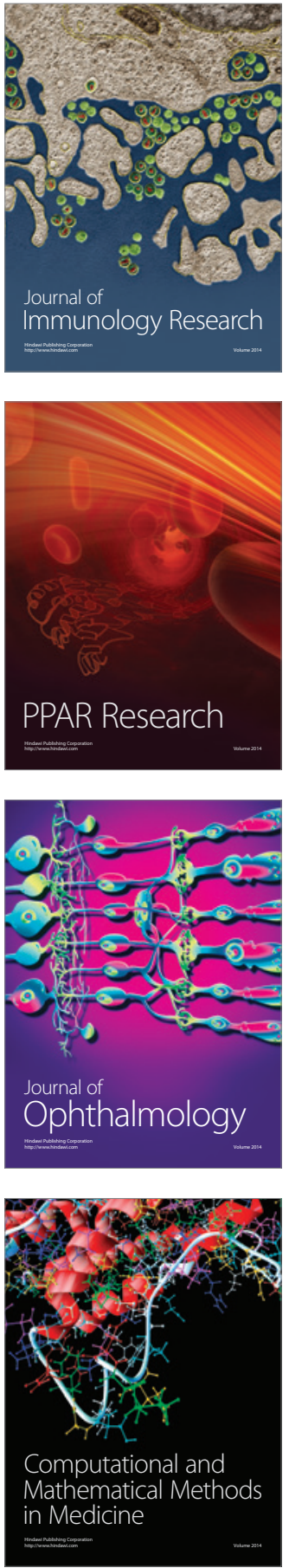

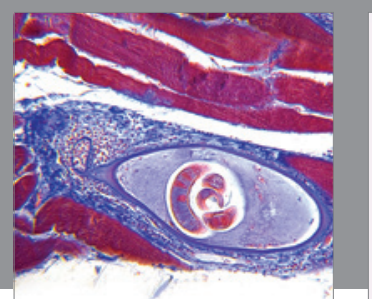

Gastroenterology Research and Practice

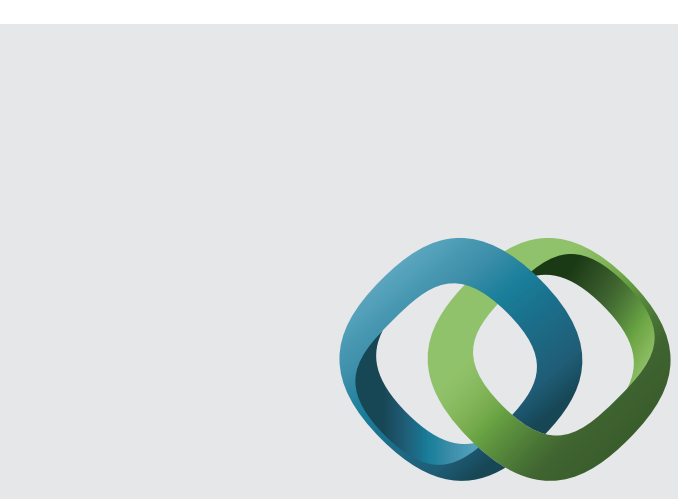

\section{Hindawi}

Submit your manuscripts at

http://www.hindawi.com
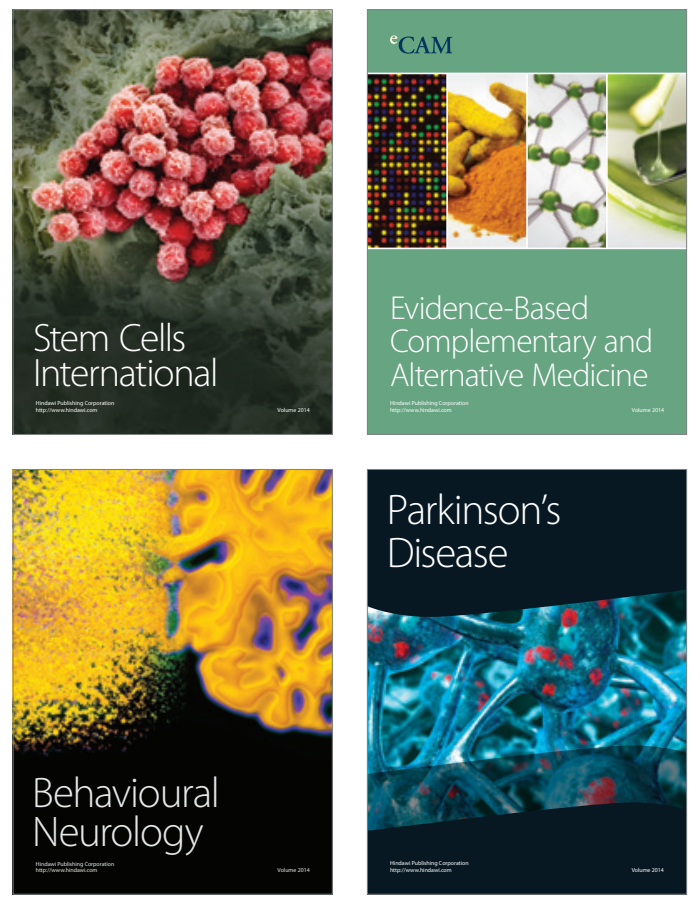
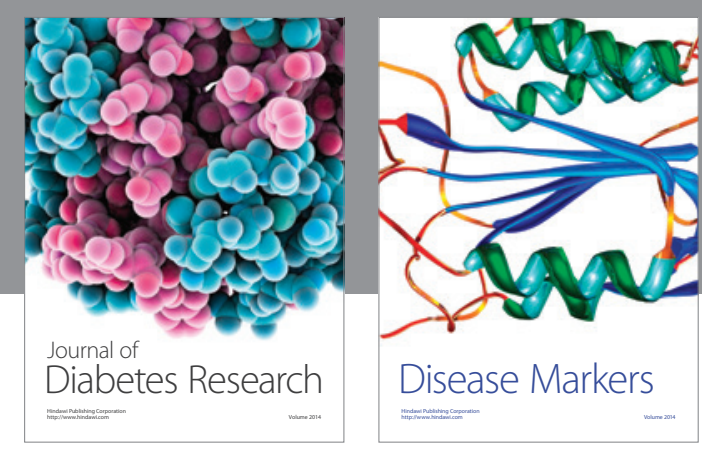

Disease Markers
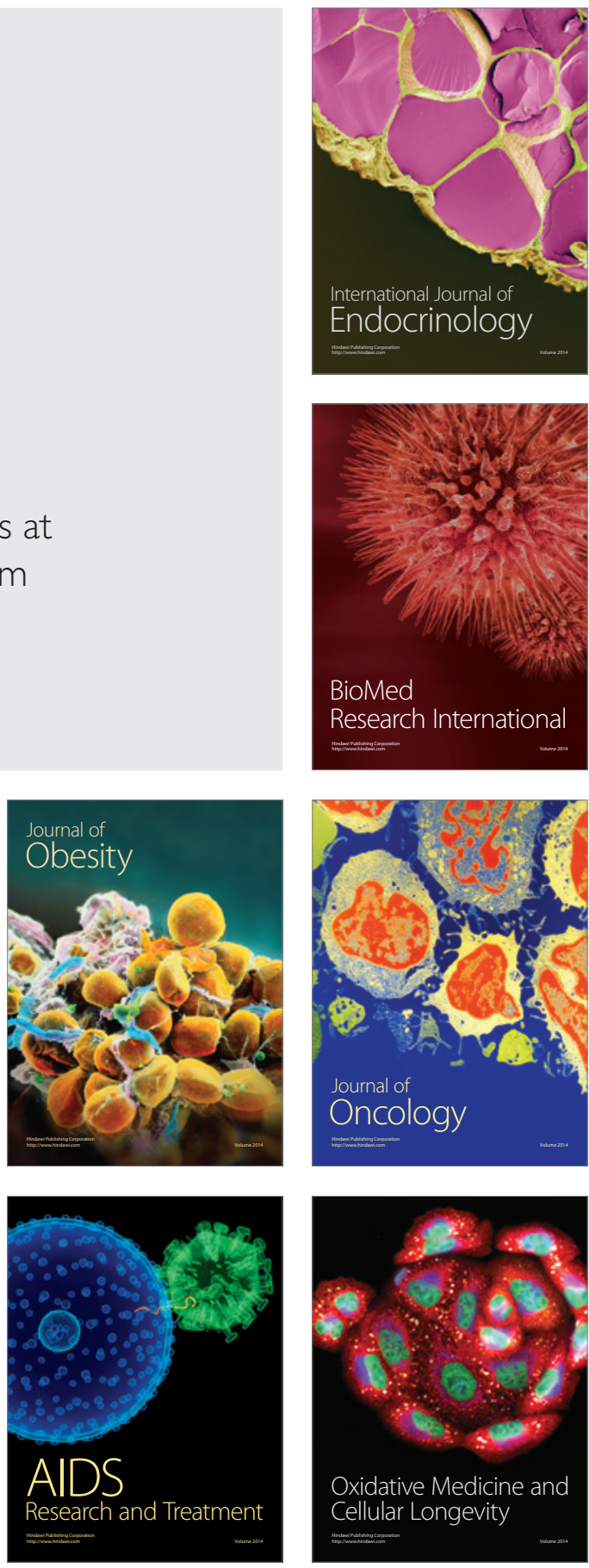